\title{
Complete genome sequence of Arcobacter nitrofigilis type strain $\left(\mathrm{CI}^{\mathrm{T}}\right)$
}

\author{
Amrita Pati ${ }^{1}$, Sabine Gronow ${ }^{3}$, Alla Lapidus ${ }^{1}$, Alex Copeland ${ }^{1}$, Tijana Glavina Del Rio ${ }^{1}$, Matt \\ Nolan ${ }^{1}$, Susan Lucas ${ }^{1}$, Hope Tice ${ }^{1}$, Jan-Fang Cheng ${ }^{1}$, Cliff Han ${ }^{1,2}$, Olga Chertkov ${ }^{1,2}$, David \\ Bruce $^{1,2}$, Roxanne Tapia ${ }^{1,2}$, Lynne Goodwin ${ }^{1,2}$, Sam Pitluck ${ }^{1}$, Konstantinos Liolios ${ }^{1}$, Natalia \\ Ivanova ${ }^{1}$, Konstantinos Mavromatis ${ }^{1}$, Amy Chen ${ }^{4}$, Krishna Palaniappan ${ }^{4}$, Miriam Land ${ }^{1,5}$, \\ Loren Hauser ${ }^{1,5}$, Yun-Juan Chang ${ }^{1,5}$, Cynthia D. Jeffries ${ }^{1,5}$, John C. Detter, ${ }^{1,2}$, Manfred Rohde ${ }^{6}$, \\ Markus Göker ${ }^{3}$, James Bristow ${ }^{1}$, Jonathan A. Eisen ${ }^{1,7}$, Victor Markowitz ${ }^{4}$, Philip Hugenholtz ${ }^{1}$, \\ Hans-Peter Klenk ${ }^{3}$, and Nikos C. Kyrpides ${ }^{{ }^{*}}$ \\ ${ }^{1}$ DOE Joint Genome Institute, Walnut Creek, California, USA \\ ${ }^{2}$ Los Alamos National Laboratory, Bioscience Division, Los Alamos, New Mexico, USA \\ ${ }^{3}$ DSMZ - German Collection of Microorganisms and Cell Cultures GmbH, Braunschweig, \\ Germany \\ ${ }^{4}$ Biological Data Management and Technology Center, Lawrence Berkeley National \\ Laboratory, Berkeley, California, USA \\ ${ }^{5}$ Oak Ridge National Laboratory, Oak Ridge, Tennessee, USA \\ ${ }^{6} \mathrm{HZI}$ - Helmholtz Centre for Infection Research, Braunschweig, Germany \\ ${ }^{7}$ University of California Davis Genome Center, Davis, California, USA
}

*Corresponding author: Nikos C. Kyrpides

Keywords: symbiotic, Spartina alterniflora Loisel, nitrogen fixation, micro-anaerophilic, motile, Campylobacteraceae, GEBA

\begin{abstract}
Arcobacter nitrofigilis (McClung et al. 1983) Vandamme et al. 1991 is the type species of the genus Arcobacter in the family Campylobacteraceae within the Epsilonproteobacteria. The species was first described in 1983 as Campylobacter nitrofigilis [1] after its detection as a free-living, nitrogen-fixing Campylobacter species associated with Spartina alterniflora Loisel roots [2]. It is of phylogenetic interest because of its lifestyle as a symbiotic organism in a marine environment in contrast to many other Arcobacter species which are associated with warm-blooded animals and tend to be pathogenic. Here we describe the features of this organism, together with the complete genome sequence, and annotation. This is the first complete genome sequence of a type stain of the genus Arcobacter. The 3,192,235 bp genome with its 3,154 protein-coding and 70 RNA genes is part of the Genomic Encyclopedia of Bacteria and Archaea project.
\end{abstract}

\section{Introduction}

Strain CI $^{\mathrm{T}}(=$ DSM $7299=$ ATCC $33309=$ CCUG 15893) is the type strain of the species Arcobacter nitrofigilis, which is the type species of the genus Arcobacter [1]. Strain $\mathrm{CI}^{\mathrm{T}}$ was isolated from roots of Spartina alterniflora Loisel (cordgrass) growing in salty marshes at the East coast of Canada. It was the first description of an organism in this kind of habitat that belonged to the genus Campylobacter, as described based on phenotypic and biochemical traits [2]. The species epithet nitrofigilis means 'nitrogen-fixing' and is based on the outstanding characteristic of this species [3]. The new genus Arcobacter, meaning 'bow-shaped rod', was introduced in 1991 and its separation from the genus Campylobacter was based on DNA-DNA and DNArRNA hybridization [1]. Up to now, the genus $A r$ cobacter comprises nine species, some of which are associated with warm-blooded animals whereas others are found in marine environments.

Within the Campylobacteraceae several wholegenome sequences have already been deciphered: A. butzleri strain RM4018 [4] (non type strain) is 
the only member of the genus Arcobacter, as well as genomes from seven species of the genus Campylobacter, and Sulfurospirillum deleyianum [5].

Only few additional strains belonging to the species $A$. nitrofigilis are known in the literature, with F2176 and F2173 [6] being the closest related ones (99\% sequence identity). The type strains of the other species of the genus Arcobacter share 93.8-94.6\% 16S rRNA sequence identity with strain $\mathrm{CI}^{\mathrm{T}}$, whereas the type strains from other genera in the family Campylobacteraceae share less than $89 \%$ sequence identity with strain $\mathrm{CI}^{\mathrm{T}}$ [7]. There are plenty of phylotypes (uncultured bacteria) known from marine environments such as the ridges flanking crustal fluids in oceanic crust (AY704399, clone FD118-51B-02, 98.6\%), sea water from Ishigaki port in Japan (AB262370/-71, 96.4\%), a mangrove of the Danshui river estuary of northern Taiwan (DQ234254, 95.8\%) [8], costal water in the Bohai Bay, China, (FJ155005, 95.8\%), in Black Sea shelf sediments in
Romania (AJ271655, 95.8\%), or from activated sludge in New Zealand (EU104146, 95.8\%). Environmental screens and marine metagenome libraries do not contain more than a handful of sequences with $>93 \%$ 16S rRNA gene sequence identity indicating a sparse representation of closely related strains in the habitats_analyzed (status March 2010). Here we present a summary classification and a set of features for A. nitrofigilis strain $\mathrm{CI}^{\mathrm{T}}$, together with the description of the complete genome sequencing and annotation.

\section{Classification and features}

Figure 1 shows the phylogenetic neighborhood of A. nitrofigilis strain $\mathrm{CI}^{\mathrm{T}}$ in a $16 \mathrm{~S}$ rRNA based tree. The four 16S rRNA gene sequences in the genome differ from each other by up to two nucleotides, and differ by up to three nucleotides from the previously published $16 \mathrm{~S}$ rRNA sequence (L14627) generated from CCUG 15893, which contains nine ambiguous base calls.

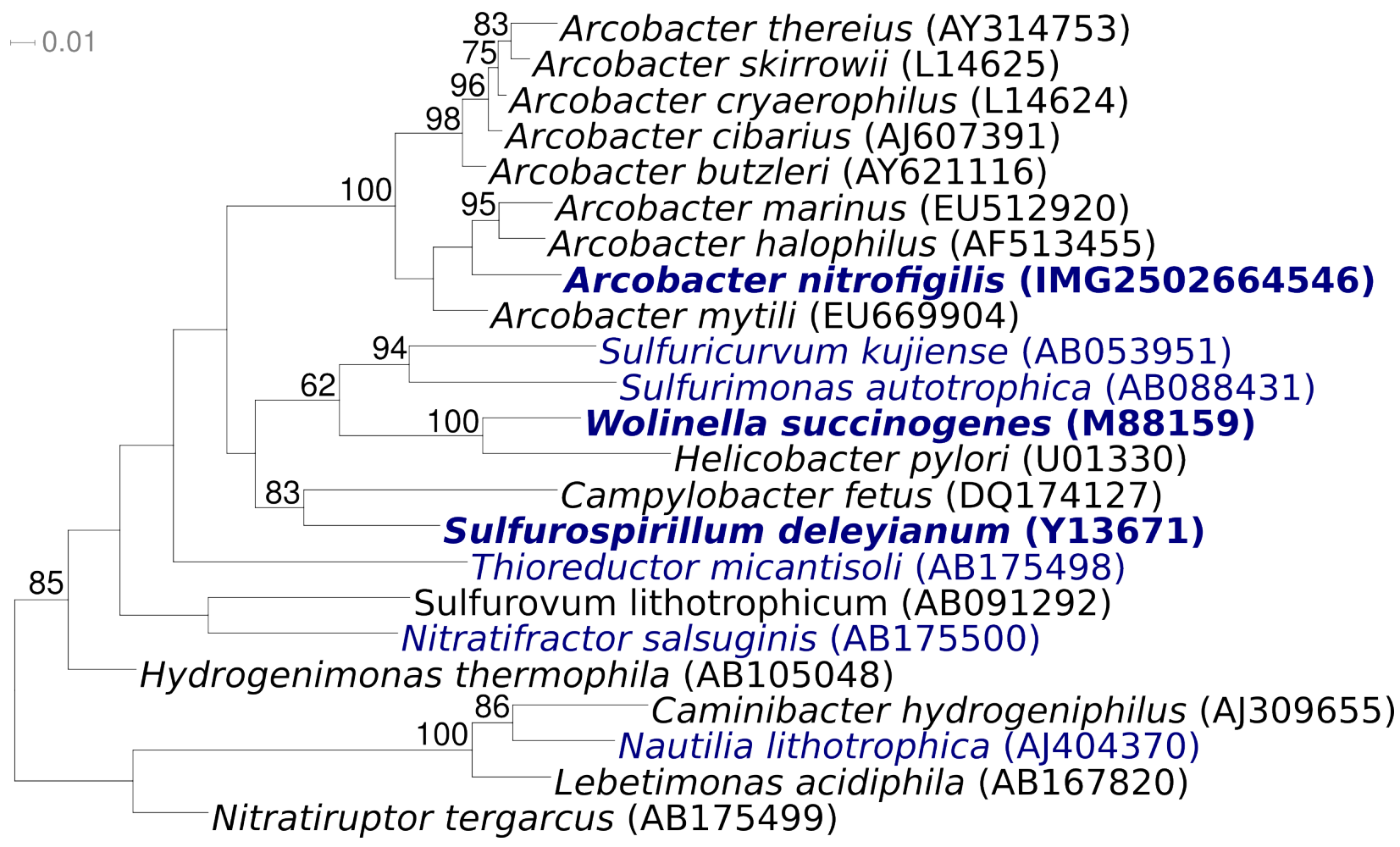

Figure 1. Phylogenetic tree highlighting the position of $A$. nitrofigilis strain $\mathrm{Cl}^{\top}$ relative to the type strains of the other genera within the Epsilonproteobacteria. The tree was inferred from 1,379 aligned characters [9,10] of the $16 \mathrm{~S}$ rRNA gene sequence under the maximum likelihood criterion [11,12] and rooted (as far as possible) in accordance with the current taxonomy [13]. The branches are scaled in terms of the expected number of substitutions per site. Numbers above branches are support values from 200 bootstrap replicates [14] if larger than $60 \%$. Lineages with type strain genome sequencing projects registered in GOLD [15] are shown in blue, published genomes [16] in bold, e.g. the recently published GEBA genome from S. deleyianum [5]. 
A. nitrofigilis cells are Gram-negative, bow-shaped or curved rods of 1-3 $\mu \mathrm{m}$ length and $0.2-0.9 \mu \mathrm{m}$ width (Figure 2 and Table 1). Motility is based on a single, polar flagellum and results in rapid corkscrew motion. Older cultures also show coccoid cells [2]. The habitat of all known A. nitrofigilis isolates is either the roots or the sediment around the roots of $S$. alterniflora Loisel growing in salt marshes [3]. Although no pathogenic association has been described so far, A. nitrofigilis was among five Arcobacter species that were isolated from food samples such as meat and shellfish varieties [27]. The optimum growth temperature of $A$. nitrofigilis is $30^{\circ} \mathrm{C}$, the temperature range is from $10-37^{\circ} \mathrm{C}$ [28]. Neither spores nor granules are present but a brown pigment is formed from tryptophan [2]. All strains of the species show positive reactions for nitrogenase, catalase and oxidase. Growth occurs under microae- rophilic conditions with oxygen as terminal electron acceptor, under anaerobic conditions fumarate or aspartate are necessary, the presence of nitrate is detrimental [2]. Hydrogen is not necessary for growth [1]. Nitrate is reduced to nitrite and sulfide is produced from cysteine [3]. Strain $\mathrm{CI}^{\mathrm{T}}$ tested positive for urease, other strains of the species do not [3]. The metabolism of $A$. nitrofigilis is chemoorganotrophic; organic acids and amino acids are used as carbon sources but carbohydrates are neither oxidized nor fermented [2]. All strains of the species are halotolerant. They require a minimum of $0.5 \% \mathrm{NaCl}$ for growth and can tolerate up to $7 \% \mathrm{NaCl}$ [28]. A. nitrofigilis is susceptible to cephalothin and nalidixic acid but isresistant to vancomycin [3]. The $\mathrm{G}+\mathrm{C}$ content of the DNA was determined by thermal denaturation to be $28.0 \%$ [3] which is slightly below the $28.4 \%$ found in the genome.

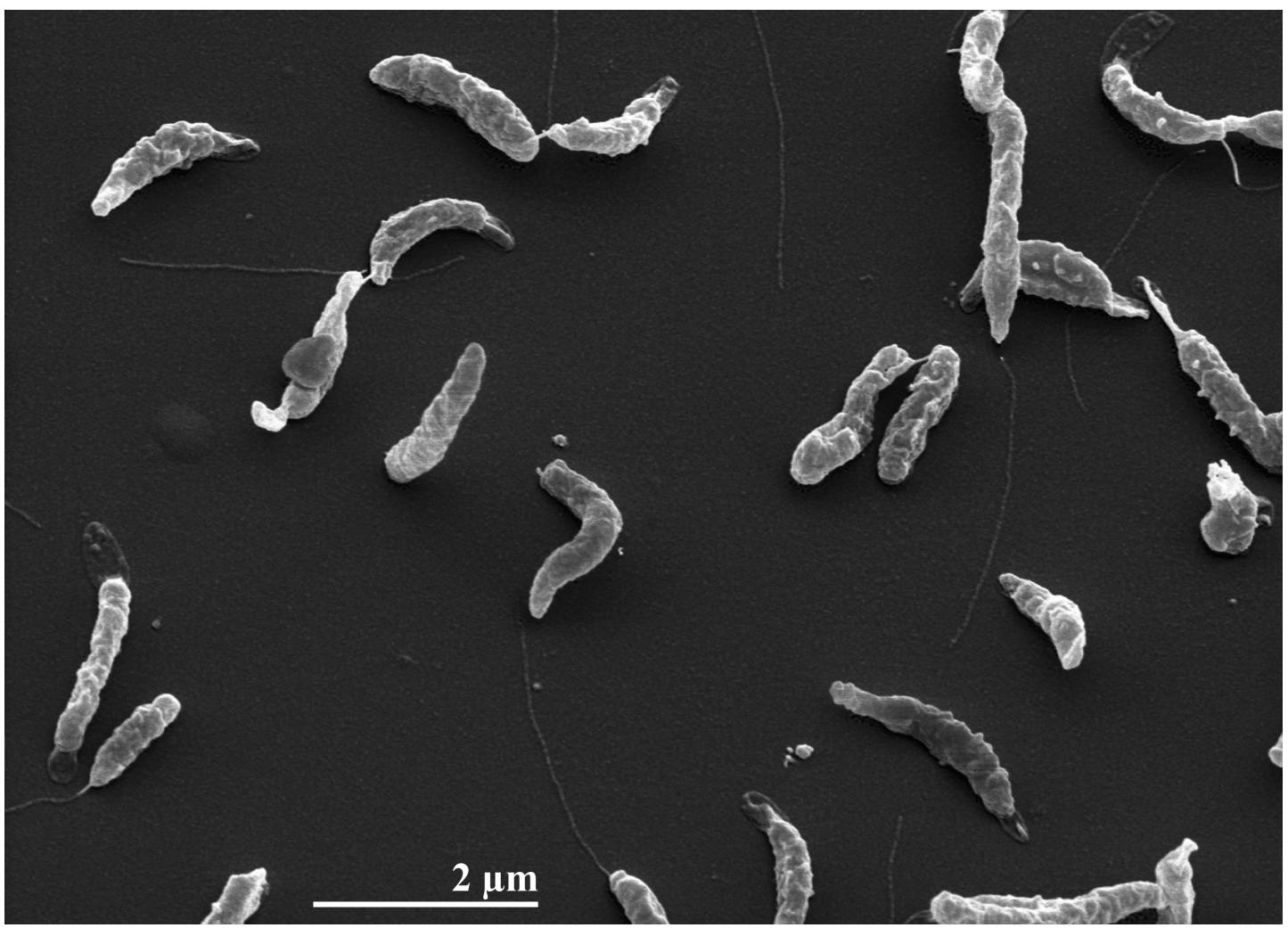

Figure 2. Scanning electron micrograph of $A$. nitrofigilis strain $\mathrm{Cl}^{\top}$

\section{Genome sequencing and annotation Genome project history}

This organism was selected for sequencing on the basis of its phylogenetic position [29], and is part of the Genomic Encyclopedia of Bacteria and Archaea project [30]. The genome project is deposited in the Genomes OnLine Database [15] and the complete genome sequence in GenBank. Sequencing, finishing and annotation were performed by the DOE Joint Genome Institute (JGI). A summary of the project information is shown in Table 2. 
Table 1. Classification and general features of A. nitrofigilis strain $\mathrm{Cl}^{\top}$ according to the MIGS recommendations [17]

\begin{tabular}{|c|c|c|c|c|}
\hline \multirow[t]{2}{*}{ MIGS ID } & \multirow[t]{2}{*}{ Property } & \multicolumn{2}{|r|}{ Term } & \multirow{2}{*}{$\begin{array}{l}\text { Evidence code } \\
\text { TAS [18] }\end{array}$} \\
\hline & & Domain & Bacteria & \\
\hline & & Phylum & 'Proteobacteria' & TAS [19] \\
\hline & & Class & Epsilonproteobacteria & TAS $[20,21]$ \\
\hline & & Order & Campylobacterales & TAS $[20,22]$ \\
\hline & & Family & Campylobacteraceae & TAS [23] \\
\hline & & Genus & Arcobacter & TAS [1] \\
\hline & Current classification & Species & Arcobacter nitrofigilis & TAS [1] \\
\hline & & Type stra & & TAS [3] \\
\hline & Gram stain & negative & & TAS [2] \\
\hline & Cell shape & bow-sha & d rods & TAS [2] \\
\hline & Motility & motile & & TAS [2] \\
\hline & Sporulation & non-spo & ating & TAS [2] \\
\hline & Temperature range & mesophi & $10-37^{\circ} \mathrm{C}$ & TAS [2] \\
\hline & Optimum temperature & $30^{\circ} \mathrm{C}$ & & TAS [24] \\
\hline & Salinity & halotole & t up to $7 \% \mathrm{NaCl}$ & TAS [2] \\
\hline \multirow[t]{3}{*}{ MIGS-22 } & Oxygen requirement & microae & hilic & TAS [2] \\
\hline & Carbon source & organic & d amino acids & TAS [1] \\
\hline & Energy source & chemoo & notroph & TAS [3] \\
\hline MIGS-6 & Habitat & marine & & TAS [2] \\
\hline MIGS-15 & Biotic relationship & symbioti & & TAS [2] \\
\hline \multirow[t]{3}{*}{ MIGS-14 } & Pathogenicity & none & & NAS \\
\hline & Biosafety level & 1 & & TAS [25] \\
\hline & Isolation & roots of $t$ & marshplant Spartina alterniflora & TAS [2] \\
\hline MIGS-4 & Geographic location & $\begin{array}{l}\text { Conrads } \\
\text { Nova Sc }\end{array}$ & $\begin{array}{l}\text { ach (Dartmouth), } \\
\text { a (Canada) }\end{array}$ & TAS [2] \\
\hline MIGS-5 & Sample collection time & about or & fore 1980 & TAS [2] \\
\hline MIGS-4.1 & Latitude & 44.65 & & NAS \\
\hline MIGS-4.2 & Longitude & -63.60 & & NAS \\
\hline MIGS-4.3 & Depth & unknow & & \\
\hline MIGS-4.4 & Altitude & sea level & & \\
\hline
\end{tabular}

Evidence codes - IDA: Inferred from Direct Assay (first time in publication); TAS: Traceable Author Statement (i.e., a direct report exists in the literature); NAS: Non-traceable Author Statement (i.e., not directly observed for the living, isolated sample, but based on a generally accepted property for the species, or anecdotal evidence). These evidence codes are from of the Gene Ontology project [26]. If the evidence code is IDA, then the property was directly observed by one of the authors or an expert mentioned in the acknowledgements.

\section{Chemotaxonomy}

The major respiratory quinones are menaquinone 6 and a second atypical menaquinone 6 that has not yet been clearly identified [1]. The major fatty acids in whole cells of $A$. nitrofigilis are hexadecenoic $\left(\mathrm{C}_{16: 0}\right)$, cis-9-hexadecenoic (cis- $\left.\mathrm{C}_{16: 1 \varpi 7 \mathrm{c}}\right)$ and cis-9-octadecenoic acid (cis- $\mathrm{C}_{\left.18: 11_{\varpi} \mathrm{c}\right)}$ [24]

\section{Growth conditions and DNA isolation}

A. nitrofigilis strain CIT, DSM 7299, was grown on DSMZ medium 429 (Columbia agar including 5\% horse blood) [31] at $28^{\circ} \mathrm{C}$. DNA was isolated from
1-1.5 g of cell paste using Qiagen Genomic 500 DNA Kit (Qiagen, Hilden, Germany) with lysis modification st/LALMP according to $\mathrm{Wu}$ et al. [30].

\section{Genome sequencing and assembly}

The genome was sequenced using a combination of Illumina and 454 technologies. An Illumina GAii shotgun library with reads of $50 \mathrm{Mb}$, a 454 Titanium draft library with average read length of 243 bases, and a paired end 454 library with average insert size 
of $24 \mathrm{~kb}$ were generated for this genome. All general aspects of library construction and sequencing can be found at http://www.jgi.doe.gov/. Draft assembly was based on $138 \mathrm{Mb} 454$ standard and 454 paired end data (498,215 reads). Newbler (Roch, version 2.0.0-PostRelease-10/28/2008) parameters are consed -a 50 -l 350 -g -m -ml 20. The initial Newbler assembly contained 42 contigs in 3 scaffolds. It was converted into a phrap assembly by making fake reads from the consensus and collecting the read pairs in the 454 paired end library. Illumina sequencing data was assembled with Velvet [32], and the consensus sequences were shredded into $1.5 \mathrm{~kb}$ overlapped fake reads and assembled together with the 454 data. The Phred/Phrap/Consed software package was used for sequence assembly and quali- ty assessment in the following finishing process. After the shotgun stage, reads were assembled with parallel phrap (High Performance Software, LLC). Possible mis-assemblies were corrected with gapResolution, Dupfinisher, or sequencing cloned bridging PCR fragments with subcloning or transposon bombing [33]. Gaps between contigs were closed by editing in Consed, by PCR and by Bubble PCR primer walks (J-F.Cheng, unpublished). A total of 480 additional Sanger reactions were necessary to close gaps and to raise the quality of the finished sequence. Illumina reads were also used to improve the final consensus quality using an in-house developed tool (the Polisher). The error rate of the completed genome sequence is less than 1 in 100,000.

Table 2. Genome sequencing project information

\begin{tabular}{|c|c|c|}
\hline MIGS ID & Property & Term \\
\hline MIGS-31 & Finishing quality & Finished \\
\hline MIGS-28 & Libraries used & $\begin{array}{l}\text { Three genomic libraries: } 454 \text { pyro-sequence } \\
\text { standard library, } 454 \text { pyro-sequence } 24 \mathrm{~kb} \\
\text { PE library, and Illumina stdandard library }\end{array}$ \\
\hline MIGS-29 & Sequencing platforms & 454 GS FLX, Illumina GAii \\
\hline MIGS-31.2 & Sequencing coverage & $43.5 \times$ pyrosequence, $15.7 \times$ Illumina \\
\hline MIGS-30 & Assemblers & $\begin{array}{l}\text { Newbler version 2.0.0-PostRelease- } \\
\text { 10/28/2008, phrap }\end{array}$ \\
\hline \multirow[t]{6}{*}{ MIGS-32 } & Gene calling method & Prodigal 1.4, GenePRIMP \\
\hline & INSDC ID & СР001999 \\
\hline & Genbank Date of Release & May 18, 2010 \\
\hline & GOLD ID & Gc01280 \\
\hline & NCBI project ID & 32593 \\
\hline & Database: IMG-GEBA & 2502545034 \\
\hline \multirow[t]{2}{*}{ MIGS-13 } & Source material identifier & DSM 7299 \\
\hline & Project relevance & Tree of Life, GEBA \\
\hline
\end{tabular}

\section{Genome annotation}

Genes were identified using Prodigal [34] as part of the Oak Ridge National Laboratory genome annotation pipeline, followed by a round of manual curation using the JGI GenePRIMP pipeline [35]. The predicted CDSs were translated and used to search the National Center for Biotechnology Information (NCBI) nonredundant database, UniProt, TIGR-Fam, Pfam, PRIAM, KEGG, COG, and InterPro databases. Additional gene prediction analysis and functional annotation was performed within the Integrated Microbial Genomes - Expert Review (IMG-ER) platform [36].

\section{Genome properties}

The genome is 3,192,235 bp long and comprises one main circular chromosome with an overall $\mathrm{G}+\mathrm{C}$ content of $28.4 \%$ (Table 3 and Figure 3). Of the 3,224 genes predicted, 3,154 were proteincoding genes, and 70 RNAs; 28 pseudogenes were also identified. The majority of the proteincoding genes $(72.1 \%)$ were assigned a putative function while those remaining were annotated as hypothetical proteins. The distribution of genes into COGs functional categories is presented in Table 4. 
Table 3. Genome Statistics

\begin{tabular}{lrr}
\hline Attribute & Value & \% of Total \\
\hline Genome size (bp) & $3,192,235$ & $100.00 \%$ \\
DNA coding region (bp) & $3,009,967$ & $94.29 \%$ \\
DNA G+C content (bp) & 905,345 & $28.36 \%$ \\
Number of replicons & 1 & \\
Extrachromosomal elements & 0 & \\
Total genes & 3,224 & $100.00 \%$ \\
RNA genes & 70 & $2.17 \%$ \\
rRNA operons & 4 & \\
Protein-coding genes & 3,154 & $97.83 \%$ \\
Pseudo genes & 70 & $2.17 \%$ \\
Genes with function prediction & 2,324 & $72.08 \%$ \\
Genes in paralog clusters & 454 & $14.08 \%$ \\
Genes assigned to COGs & 2,363 & $73.29 \%$ \\
Genes assigned Pfam domains & 2,480 & $76.92 \%$ \\
Genes with signal peptides & 597 & $18.52 \%$ \\
Genes with transmembrane helices & 838 & $25.99 \%$ \\
CRISPR repeats & 1 & \\
\hline
\end{tabular}

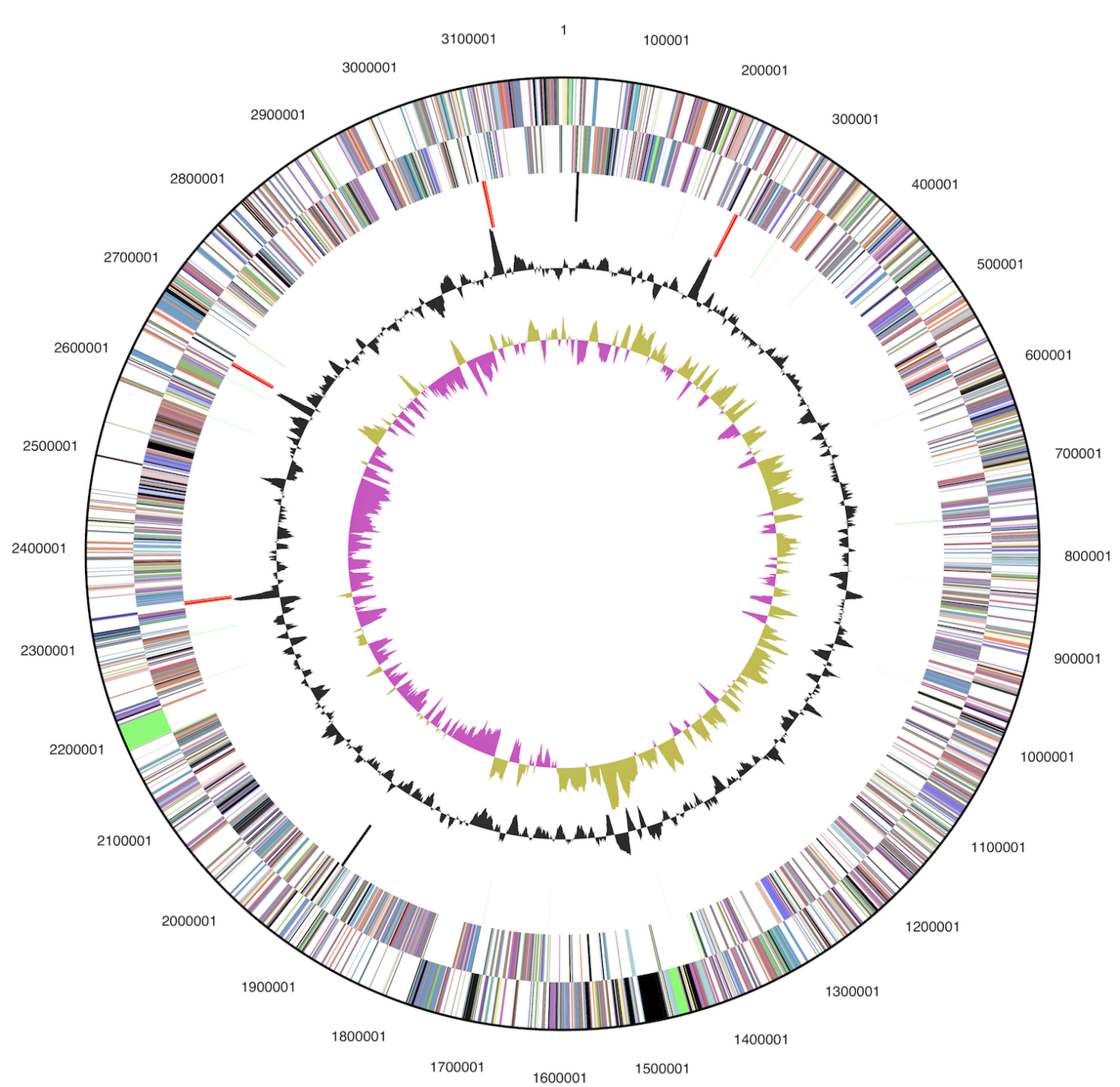

Figure 3. Graphical circular map of the chromosome. From outside to the center: Genes on forward strand (color by COG categories), Genes on reverse strand (color by COG categories), RNA genes (tRNAs green, rRNAs red, other RNAs black), GC content, GC skew. 
Table 4. Number of genes associated with the general COG functional categories

\begin{tabular}{crrl}
\hline Code & value & \%age & Description \\
\hline J & 143 & 5.4 & Translation, ribosomal structure and biogenesis \\
A & 0 & 0.0 & RNA processing and modification \\
K & 157 & 5.9 & Transcription \\
L & 102 & 3.9 & Replication, recombination and repair \\
B & 0 & 0.0 & Chromatin structure and dynamics \\
D & 16 & 0.6 & Cell cycle control, mitosis and meiosis \\
Y & 0 & 0.0 & Nuclear structure \\
V & 37 & 1.4 & Defense mechanisms \\
T & 267 & 10.1 & Signal transduction mechanisms \\
M & 168 & 6.3 & Cell wall/membrane/envelope biogenesis \\
N & 78 & 3.0 & Cell motility \\
Z & 0 & 0.0 & Cytoskeleton \\
W & 0 & 0.0 & Extracellular structures \\
U & 69 & 2.6 & Intracellular trafficking and secretion \\
O & 103 & 3.9 & Posttranslational modification, protein turnover, chaperones \\
C & 212 & 8.0 & Energy production and conversion \\
G & 114 & 4.3 & Carbohydrate transport and metabolism \\
E & 252 & 9.5 & Amino acid transport and metabolism \\
F & 61 & 2.3 & Nucleotide transport and metabolism \\
H & 128 & 4.8 & Coenzyme transport and metabolism \\
I & 57 & 2.2 & Lipid transport and metabolism \\
P & 159 & 6.0 & Inorganic ion transport and metabolism \\
Q & 38 & 1.4 & Secondary metabolites biosynthesis, transport and catabolism \\
R & 288 & 10.9 & General function prediction only \\
S & 199 & 7.5 & Function unknown \\
- & 861 & 26.1 & Not in COGs \\
\hline & & &
\end{tabular}

\section{Acknowledgements}

We would like to gratefully acknowledge the help of Sabine Welnitz for growing the A. nitrofigilis cells, and Susanne Schneider for DNA extraction and quality analysis (both at DSMZ). This work was performed under the auspices of the US Department of Energy Office of Science, Biological and Environmental Research Program, and by the University of California, Lawrence Berkeley National Laboratory under contract No. DE-

\section{References}

1. Vandamme P, Falsen E, Rossau R, Hoste B, Segers P, Tytgat RDE, Ley J. Revision of Campylobacter, Helicobacter, and Wolinella taxonomy: emendation of generic descriptions and proposal of Arcobacter gen. nov. Int J Syst Bacteriol 1991; 41:88103. PubMed doi:10.1099/00207713-41-1-88

2. McClung CR, Patriquin DG. Isolation of a nitrogen-fixing Campylobacter species from the roots of Spartina alterniflora Loisel. Can J Microbiol
AC02-05CH11231, Lawrence Livermore National Laboratory under Contract No. DE-AC52-07NA27344, Los Alamos National Laboratory under contract No. DEAC02-06NA25396, and UT-Battelle Oak Ridge National Laboratory under contract DE-AC05-000R22725, as well as German Research Foundation (DFG) INST 599/1-2.
1980; 26:881-886. PubMed doi:10.1139/m80$\underline{153}$

3. McClung CR, Patriquin DG, Davis RE. Campylobacter nitrofigilis sp. nov. a nitrogen-fixing bacterium associated with roots of Spartina alterniflora Loisel. Int / Syst Bacteriol 1983; 33:605-612. doi:10.1099/00207713-33-3-605

4. Miller WG, Parker CT, Rubenfeld M, Mendz GL, Wösten MMS, Ussery DW, Stolz JF, Binnewies TT, Hallin PF, Wang G, et al. The complete ge- 
nome sequence and analysis of the Epsilonproteobacterium Arcobacter butzleri. PLOS ONE 2007; 2:e1358. PubMed doi:10.1371/journal.pone.0001358

5. Sikorski J, Lapidus A, Copeland A, Glavina Del Rio T, Nolan M, Lucas S, Chen F, Tice H, Cheng JF, Saunders E, et al. Complete genome of Sulfurospirillum deleyianum type strain $\left(5175^{\top}\right)$. Stand Genomic Sci 2010; 2:149-157.

doi:10.4056/sigs.671209

6. Figueras MJ, Collado L, Guarro J. A new $16 \mathrm{~S}$ rRNA-RFLP method for the discrimination of the accepted species of Arcobacter. Diagn Microbiol Infect Dis 2008; 62:11-15. PubMed doi:10.1016/j.diagmicrobio.2007.09.019

7. Chun J, Lee JH, Jung Y, Kim M, Kim S, Kim BK, Lim YW. EzTaxon: a web-based tool for the identification of prokaryotes based on $16 \mathrm{~S}$ ribosomal RNA gene sequences. Int / Syst Evol Microbiol 2007; 57:2259-2261. PubMed doi:10.1099/ijs.0.64915-0

8. Liao PC, Huang BH, Huang S. Microbial community composition of the Danshui river estuary of northern Taiwan and the practicality of the phylogenetic method in microbial barcoding. Microb Ecol 2007; 54:497-507. PubMed doi:10.1007/s00248-007-9217-2

9. Castresana J. Selection of conserved blocks from multiple alignments for their use in phylogenetic analysis. Mol Biol Evol 2000; 17:540-552. PubMed

10. Lee C, Grasso C, Sharlow MF. Multiple sequence alignment using partial order graphs. Bioinformatics 2002; 18:452-464. PubMed doi:10.1093/bioinformatics/18.3.452

11. Stamatakis A, Hoover P, Rougemont J. A Rapid Bootstrap Algorithm for the RAxML Web Servers. Syst Biol 2008; 57:758-771. PubMed doi:10.1080/10635150802429642

12. Felsenstein J. Evolutionary trees from DNA sequences: a maximum likelihood approach. J Mol Evol 1981; 17:368-376. PubMed doi:10.1007/BF01734359

13. Yarza P, Richter M, Peplies J, Euzeby JP, Amann $\mathrm{R}$, Schleifer KH, Ludwig W, Glöckner FO, Rossello-Mora R. The All-Species Living Tree project: A $16 \mathrm{~S}$ rRNA-based phylogenetic tree of all sequenced type strains. Syst Appl Microbiol 2008; 31:241-250. PubMed doi:10.1016/j.syapm.2008.07.001

14. Pattengale ND, Alipour M, Bininda-Emonds ORP, Moret BME, Stamatakis A. How Many Bootstrap
Replicates Are Necessary? Lect Notes Comput Sci 2009; 5541:184-200. doi:10.1007/978-3-642$\underline{02008-7 \quad 13}$

15. Liolios K, Chen IM, Mavromatis K, Tavernarakis N, Hugenholtz P, Markowitz VM, Kyrpides NC. The Genomes On Line Database (GOLD) in 2009: status of genomic and metagenomic projects and their associated metadata. Nucleic Acids Res 2010; 38:D346-D354. PubMed doi:10.1093/nar/gkp848

16. Baar C, Eppinger M, Raddatz G, Simon J, Lanz C, Klimmek O, Nandakumar R, Gross R, Rosinus A, Keller $\mathrm{H}$, et al. Complete genome sequence and analysis of Wolinella succinogenes. Proc Natl Acad Sci USA 2003; 100:11690-11695. PubMed doi:10.1073/pnas.1932838100

17. Field D, Garrity G, Gray T, Morrison N, Selengut J, Sterk P, Tatusova T, Thompson N, Allen MJ, Anguiuoli SV, et al. Towards a richer description of our complete collection of genomes and metagenomes: the "Minimum Information about a Genome Sequence" (MIGS) specification. Nat Biotechnol 2008; 26:541-547. PubMed doi:10.1038/nbt1360

18. Woese CR, Kandler O, Wheelis ML. Towards a natural system of organisms: proposal for the domains Archaea, Bacteria, and Eucarya. Proc Natl Acad Sci USA 1990; 87:4576-4579. PubMed doi:10.1073/pnas.87.12.4576

19. Garrity GM, Holt JG. The Road Map to the Manual. In: Garrity GM, Boone DR, Castenholz RW (eds), Bergey's Manual of Systematic Bacteriology, Second Edition, Volume 1, Springer, New York, 2001, p. 119-169.

20. Validation List No. 107. List of new names and new combinations previously effectively, but not validly, published. Int / Syst Evol Microbiol 2006; 56:1-6. PubMed doi:10.1099/ijs.0.64188-0

21. Garrity GM, Bell JA, Lilburn T. Class V. Epsilonproteobacteria class. nov. In: Garrity GM, Brenner DJ, Krieg NR, Staley JT (eds), Bergey's Manual of Systematic Bacteriology, Second Edition, Volume 2, Part C, Springer, New York, 2005, p. 1145.

22. Garrity GM, Bell JA, Lilburn T. Order I. Campylobacterales ord. nov. In: Garrity GM, Brenner DJ, Krieg NR, Staley JT (eds), Bergey's Manual of Systematic Bacteriology, Second Edition, Volume 2, Part C, Springer, New York, 2005, p. 1145.

23. Vandamme $P$, De Ley J. Proposal for a new family, Campylobacteraceae. Int I Syst Bacteriol 1991; 41:451-455. doi:10.1099/00207713-41-3-451 
24. Donachie SP, Bowman JP, On SL, Alam M. Arcobacter halophilus sp. nov., the first obligate halophile in the genus Arcobacter. Int / Syst Evol Microbiol 2005; 55:1271-1277. PubMed doi:10.1099/ijs.0.63581-0

25. Classification of. Bacteria and Archaea in risk groups. www.baua.de TRBA 466.

26. Ashburner M, Ball CA, Blake JA, Botstein D, Butler H, Cherry JM, Davis AP, Dolinski K, Dwight SS, Eppig JT, et al. Gene ontology: tool for the unification of biology. Nat Genet 2000; 25:25-29. PubMed doi:10.1038/75556

27. Collado L, Guarro J, Figueras MJ. Prevalence of Arcobacter in meat and shellfish. J Food Prot 2009; 72:1102-1106. PubMed

28. Tenover FC, Fennell CL. The genera Campylobacter and Helicobacter. In: The Prokaryotes. Vol. IV, $2^{\text {nd }}$ ed. 1992, Springer-Verlag, New York.

29. Klenk HP, Göker M. En route to a genome-based taxonomy of Archaea and Bacteria? Syst Appl Microbiol 2010; 33:175-182. PubMed doi:10.1016/j.syapm.2010.03.003

30. Wu D, Hugenholtz P, Mavromatis K, Pukall R, Dalin E, Ivanova N, Kunin V, Goodwin L, Wu M, Tindall BJ, et al. A phylogeny-driven genomic encyclopedia of Bacteria and Archaea. Nature 2009; 462:1056-1060. PubMed doi:10.1038/nature08656
31. List of growth media used at DSMZ: http://www.dsmz.de/microorganisms/media_list.p hp.

32. Zerbino DR, Birney E. Velvet: algorithms for de novo short read assembly using de Bruijn graphs. Genome Res 2008; 18:821-829. PubMed doi:10.1101/gr.074492.107

33. Sims D, Brettin T, Detter JC, Han C, Lapidus A, Copeland A, Glavina Del Rio T, Nolan M, Chen F, Lucas S, et al. Complete genome of Kytococcus sedentarius type strain $\left(541^{\top}\right)$. Stand Genomic Sci 2009; 1:12-20. doi:10.4056/sigs.761

34. Hyatt D, Chen GL, Locascio PF, Land ML, Larimer FW, Hauser LJ. Prodigal Prokaryotic Dynamic Programming Genefinding Algorithm. BMC Bioinformatics 2010; 11:119. PubMed doi:10.1186/1471-2105-11-119

35. Pati A, Ivanova N, Mikhailova N, Ovchinikova G, Hooper SD, Lykidis A, Kyrpides NC. GenePRIMP: A Gene Prediction Improvement Pipeline for microbial genomes. Nat Methods 2010; 7:455-457. PubMed doi:10.1038/nmeth.1457

36. Markowitz VM, Ivanova NN, Chen IMA, Chu K, Kyrpides NC. IMG ER: a system for microbial genome annotation expert review and curation. Bioinformatics 2009; 25:2271-2278. PubMed doi:10.1093/bioinformatics/btp393 